\title{
Engineering and Technology Education Fields: Providing Synthesis and Knowl- edge through Historical Perspectives
}

\author{
Mr. Presentacion Rivera-Reyes, Utah State University - Engineering Education
}

Presentacion Rivera-Reyes is currently a graduate teaching assistant and a PhD student in the Engineering Education Department at Utah State University. He formerly held a position as Professor of Telecommunication Engineering at Technological University of Honduras. He received his B.S. in Electrical Engineering from the National Autonomous University of Honduras. He has experience in the telecommunication industry where he worked training engineers and technicians in high-speed transmission system for backbone networks.

\section{Dr. Oenardi Lawanto, Utah State University}

Oenardi Lawanto is an assistant professor in the Department of Engineering Education at Utah State University, USA. He received his B.S.E.E. from Iowa State University, his M.S.E.E. from the University of Dayton, and his Ph.D. from the University of Illinois at Urbana-Champaign. Before coming to Utah State, Dr. Lawanto taught and held several administrative positions at one large private university in Indonesia. In his years of teaching experiences in the area of electrical engineering, he has gained new perspectives on teaching and learning. He has developed and delivered numerous workshops on student-centered learning and online-learning-related topics during his service in Indonesia. Dr. Lawanto's research interests include cognition, learning, and instruction, and online learning.

\section{Mr. Raymond Edward Boyles, Technology and Engineering Education}

Raymond Edward Boyles has an associate's in specialized, avionics, May 1992, from Pittsburgh Institute of Aeronautics, and a B.S., information technology, May 2008, and M.S., technology education, Aug. 2009, from California University of PA. Most Relevant Papers: Santoso, H., Boyles, R., Lawanto, O. \& Goodridge, W. (2011). A Preliminary Study of Conducting Semi-Structured Interview as Metacognitive Assessment in Engineering Design: Issues and Challenges. American Society for Engineering Education. Presentations, five most relevant: TeleRobotics: The Internet, a Physical Sensor 73rd Annual Conference Program, ITEEA 2011. Dr. Kallis, J., Boyles, R. Implementation of Microgravity Experiments in the Classroom 73rd Annual Conference Program, ITEEA 2011 Teaching STEM Concepts with Agile Robotics. Dr. Kallis, J., Boyles, R. 73rd Annual Conference Program, ITEEA 2009. Tremaux's Algorithm with Recursion 73rd Annual Conference Program, ITEEA 2009. "Normalcy" 2008 Intercollegiate Art Show, Best of Show, California University of PA, April 3rd, 2008. "Die Verfeinerung von Sustainability" Create the Future Design Contest, NASA Tech Briefs and SolidWorks, Oct. 14, 2008. "Teaching by strong interest through analogous Java Software," 56th Annual TEAP Conference. Harrisburg, Penn., Nov. 6-7, 2008. "G.S.Ohm: Electrical Innovation in Industry." Poster presentation at National Collegiate Honors Council Conference, Philadelphia, Penn., Nov. 17, 2006. "Societas crescit: Invention and Innovation through Team Teaching." Panel presentation at National Collegiate Honors Council Conference, Philadelphia, Penn., Nov. 16, 2006. Major Collaborators: Prof. John R. Kallis (California University of Pa.) Graduate Advisor: Prof. Gary Stewardson (Utah State University). Military: U.S. Army, Fort Carson, Colo. Unit Administrative Specialist (Dec. 1998-April 1999), duties: Created and maintained databases for 231 soldiers; responsible for processing all information on incoming and outgoing personnel databases implementation saved 18\% manpower. Nuclear Chemical Biological Specialist (Jan. 1998-Dec. 1998), duties: Maintained, overhauled and calibrated all chemical equipment; trained soldiers in how to React in certain NBC situations. Fire Control Repairer, duties: Served as a shop foreman; supervised eight personnel which were responsible for repairing electronic fire control equipment; repaired all electronic equipment on the M!A! and Bradley tanks; and maintained records of cost and requisitioned funding from battalion. Saved 65\% in cost by performing office computer repairs. Military Achievements: Two Army Achievement medals, Army Good Conduct Medal, National Defense Service Medal, Army Lapel Button, Army Service Ribbon, Expert Marksmanship Qualification Badge with Grenade Bar, and Marksman 
Marksmanship Qualification Badge with Rifle Bar. Work Experience: Utah State University, Jan. 2010 to present, instructor for ETE 1020 energy, power, transportation systems control technology exploration of the concepts and processes relating to the control and automation (both hard and programmable) of technical systems in the areas of energy and power, transportation, and agricultural and related biotechnologies. California University of PA, Jan. 2008 to May 2009, Teaching Assistant. Assisted the professor in class preparation, lesson plans, and distribution of materials Also gain teaching experience by lecturing the class section which deals with programming robots. Managed a laboratory, which allowed students to complete experiments. AT\&T Broadband, Pittsburgh Penn., May 2000 to Dec. 2002, Head end Technician, responsible for all aspects of high speed data, telephony and cable operations, hybrid fiber to coax transmissions, programming in Visual Basic, C++, Java scripting, and M.S. Office. Experience with systems such as Cheetah, Path Tracks, and Cornerstone. Access Bandwidth Technician, responsible for implementing and maintaining telephony network systems for the Pittsburgh and surrounding areas. Data basing and systems programmer for repairs on nodal analysis and problem solving, Heilig-Meyers Furniture Company, Richmond, Va., Aug.1994-Nov. 1994, Network/Telephone/Alarm System Installer, traveled throughout the United States to install computer networks, telephone and alarm systems, which also included maintenance and repair. Guardian Glass Corporation, Floreffe, Penn., Electrical Maintenance Technician, Nov. 1993-June 1994, installed PLC systems (Allen-Bradley); repaired and maintained laser systems, photo helix, pyrometers, and integrated control systems for network operations. WLTJ-WRRK radio station, installed and calibrated all transmission equipment for this radio station. 


\title{
Engineering and Technology Education Fields: Providing Synthesis and
}

\author{
Knowledge through Historical Perspectives
}

\begin{abstract}
The purpose of this paper is to address misconceptions that exist in the educational community in regards to the definitions of engineering education, technology education, and engineering \& technology education. The misconceptions can be addressed by exploring how these occupational fields have emerged and how the terminology, associated with each field, is defined. Identifying these fields in a historical perspective, and the co-existing associated fields, will show the misconceptions and bridge professional knowledge about these complex and collective fields.
\end{abstract}

If misconceptions exist, how the community values these fields and how they can be subjective toward the roles of the professionals and educators involved. There exists evidence that the community confuses these fields' terminologies as well. An example could be how the term "technology" is understood. In 2004, 68\% of the American population interpreted the word "technology" synonymously with the concepts of computers, electronics, and the Internet.

Misconceptions and skewed assumptions of these educational fields and associated terms can be due to lack of knowledge about the foundations of these fields. Because the foundations are confused, conflict, disagreement, and differences of opinion in academia and work environments seem prevalent. To distinguish the roles of the professionals involved in engineering education, technology education, and engineering \& technology education fields will allow an understanding for how the community should interprets and interacts with these fields.

Historical perspectives can be utilized to form an understanding of the collective natures of these fields. Dating back to the first professional associations, and chronologically advancing to the present, historical research will uncover the terms and distinctions necessary to establish both an understanding and a synthesis of how these current fields have emerged. Chronological events can be linked to provide the foundations of engineering education, technology education, and engineering \& technology education.

\section{Introduction}

There is confusion today to define concepts or activities related to the terms "technology" and "engineering". Society tends to confuse the term technology with science, when technology is concerned with "what can or should be through modification of the natural world, and science is very concerned with what is (exist) in the natural world. Also, public opinion inclines to relate the term technology with computers, electronics, and the Internet" ${ }^{[4]}$. Public opinion and society tend to confuse some task and duties associated to engineer or technician. In the simplest of terms, public opinion does not recognize that an engineer is a problem solver, and a technician is 
a "doer", a highly trained worker to perform specific tasks ${ }^{[20]}$. Also in occupational field, there are misconceptions of real role of engineers and technicians in hand-on activities. Dating back to the history and chronologically advancing to the present, historical research will expose these terms and will give us understanding of who these terms emerged from postsecondary education, general education, and vocational education with their precursors.

\section{Historical perspective}

The foundations of Engineering Education are historically linked to certain founding fathers and historic events. Names such as Stillman Robinson, Victor Della Vos, Calvin Runkle, and John Woodward were major contributors to engineering and design in post secondary education. Historical events can consist of the engineering movements, the arts and craft movement, and Sloyd movement. Although the movements, founding fathers and the events are a small part of the post secondary institution the joint created a pathway of understanding post secondary education for education, agriculture and industry. A delivery method is critical in education because the delivery method must accommodate students with resources. The project method, used in the late $20^{\text {th }}$ century is still in use today.

Stillman H. Robinson, Professor of Mechanical Engineering at the Illinois Industrial University at Urbana, believed through industrial demands that engineering required craftsman apprenticeship. The idea of the project method was a vehicle to combine hands on training with engineering studies ${ }^{[12]}$. The project method of teaching, although fitting for Robinson, offered one flaw in that it was time-consuming. A new system that offered organization and allotted time to gain knowledge and skills necessary for employment would emerge. Robinson's method would be altered by the Russians. The Russian system of Victor Della Vos, demonstrated to the American public at the Philadelphia Exposition of 1876, allotted the time necessary to combine hand on training with class work. The system appropriated the term manual training in manual and industrial education; also termed manual arts and manual training ${ }^{[3]}$. The Russian system introduced a method that allotted more time for the students to conduct research and consisted of six constructs: (1) There are several workshops; each containing different instructions. (2) There were enough work stations to accommodate all the pupils. (3) Arrangement of the stations signified the increase the difficulty level. (4) Because all the models are in drawings, each student received copies. (5) The drafting class created the drawings. (6) No student can move to the next station until they have acceptably completed the previous mode ${ }^{[3]}$. According to the Russian system model if a student does not complete a station then this student will repeat the station.

The display of the Russian tool system may have motivated Calvin Woodward, President of Massachusetts Institute of Technology (MIT), to found the first Manual Training School. In this school, students became acquainted with the art of handicrafts in two phases: (1) by passing through a series of basic exercises, students received instruction on the basics of tools and techniques, (2) students were also expected to develop and carry out "projects" independently ${ }^{[12]}$. As with the Russian system the school of manual arts required students to show a project that gained the approval of the faculty from the manual arts school. The project consists of constructing a machine combined with the machines drawings accompanied with the casting 
molds ${ }^{[12]}$. This curriculum approach may suggest what would be called today engineering technology or hands on engineering.

John D. Runkle (Washington University), who may have also been inspired by the Russian tool system, was agreed with Woodward that engineering education would need hands-on experience ${ }^{[3]}$. Runkle created curriculum at MIT for the mechanical arts laboratories ${ }^{[3]}$. Runkle referred to this educational method by claiming the method, taken from the Russian tool system, not only offers education but attributes as a philosophical key to all industrial education ${ }^{[3]}$. Both Woodward and Runkle were preparing engineers to enter the occupational demands that need hands on experience combined with intense theory.

Charles Richards claimed that America presumes "our place as a nation practically at the time of the industrial revolution" ${ }^{[18]}$. One lacking feature, during this time, is that America had no artistic traditions except for those of other countries and the United States (U.S.) needed to develop their own artistic tradition. The arts and crafts movement entered the U.S. by England in the early 1880's and demonstrated in the schools of Philadelphia ${ }^{[19]}$. The arts and crafts movement, in the early 1880's was increasingly absorbed into art education by $1912^{[8]}$. In the U.S., the terms associated with manual arts, industrial arts, household arts, handiwork, arts and crafts and practical training, are often used to denote the style of architecture, interior design, and decorative arts in education that prevailed between the dominant eras during the years of $1920 \mathrm{~s}^{[8]}$.

\section{General Education and Manual Training}

In 1906 the Douglas Commission demanded industrial education of trades: vocational education. The report produced by Douglas commission identified the idea that general educators like Dewey, Froebel, and Pestalozzi, who defined manual training as education because there were social and moral values added to the knowledge of vocation, was part of a problem because industry needed workers but not educators ${ }^{[2]}$. Industry was attempting to redefine general educations mission but impact from Pestalozzi and Dewey may have caused Oswego Teachers' College to take their place in leadership of Manual Training. The New York Educational department trained industrial arts teachers and recognized the leadership of Pestalozzi and Dewey ${ }^{[3]}$. Fredrick Bonser and Louis Russell were implementing Social-Industrial Theory to add the social and culture context required by general education ${ }^{\text {[6] }}$. The need for trades however influenced manual training practices with the lacked social and cultural context. The industrial need disregarded the girth of Dewey's philosophy towards manual training ${ }^{[2]}$. Industrial needs created the bifurcation between general education and vocational education, and the bifurcation assigned agriculture as a catalyst to meet the goals of three types of schools: general educational, agricultural, and vocational institutions. Vocational education had developmental issues that focused on funding.

\section{Manual Training and Vocational Education}

The vocational education movement in American identifies with the report of the Commission on Industrial and Technical Education for the Commonwealth of Massachusetts in $1906^{[14]}$. Federal and State support was already established due to the Morrill Act of 1862 which may 
have established methods of federal funding for vocational education. The act allotted states land to sell and build institutions. The proceeds from the sold land would allow fund the startup of the state educational institutions. These state institutions focused on agriculture and engineering. Local and private sources funded training and education before several versions of the Morrill Act were in place ${ }^{[13]}$. The Smith Hughes Act of 1917 was in response to reaffirm the land grant charter focused on Vocational Education ${ }^{[10]}$. Vocational education was not directed solely at industry however, the Morrill Act demonstrated agriculture and engineering. Industry suggested vocation, but agriculture suggested vocational education as well. Industry abandoned Pestalozzi's and Dewey's beliefs.

World War II led to a significant expansion of Federal support for education. The Lanham Act in 1941, which is a copyright law ${ }^{[1]}$, and the Impact Aid laws of 1950 eased the burden on communities affected by the military and other Federal installations by making payments to school districts ${ }^{[16]}$. Technology was not just taking place in the U.S. The launching of Sputnik was a historical event that produced great fear in the American government ${ }^{[7]}$. The government's reaction to Sputnik provided the vocational community with increased funding. The launch caused the U.S. Federal government re-explore education and focuses on the scientific and technical education community ${ }^{[9]}$. The governments created an organization titled the National Defense Education Act in response to Sputnik that overseen the funding and implementation of curriculum $^{[15]}$. A current funding source known as the Carl D. Perkins Career and Technical Education Act holds accountability requirements in exchange to federal funds under this act to offer overall leadership. The Act, which offers supervision, maintains a relationship with the Office of Vocational and Adult Education ${ }^{[17]}$. Many other services now exist such as federally funded and state funded vocational rehabilitation services that offer training for employment (See Figure 1).

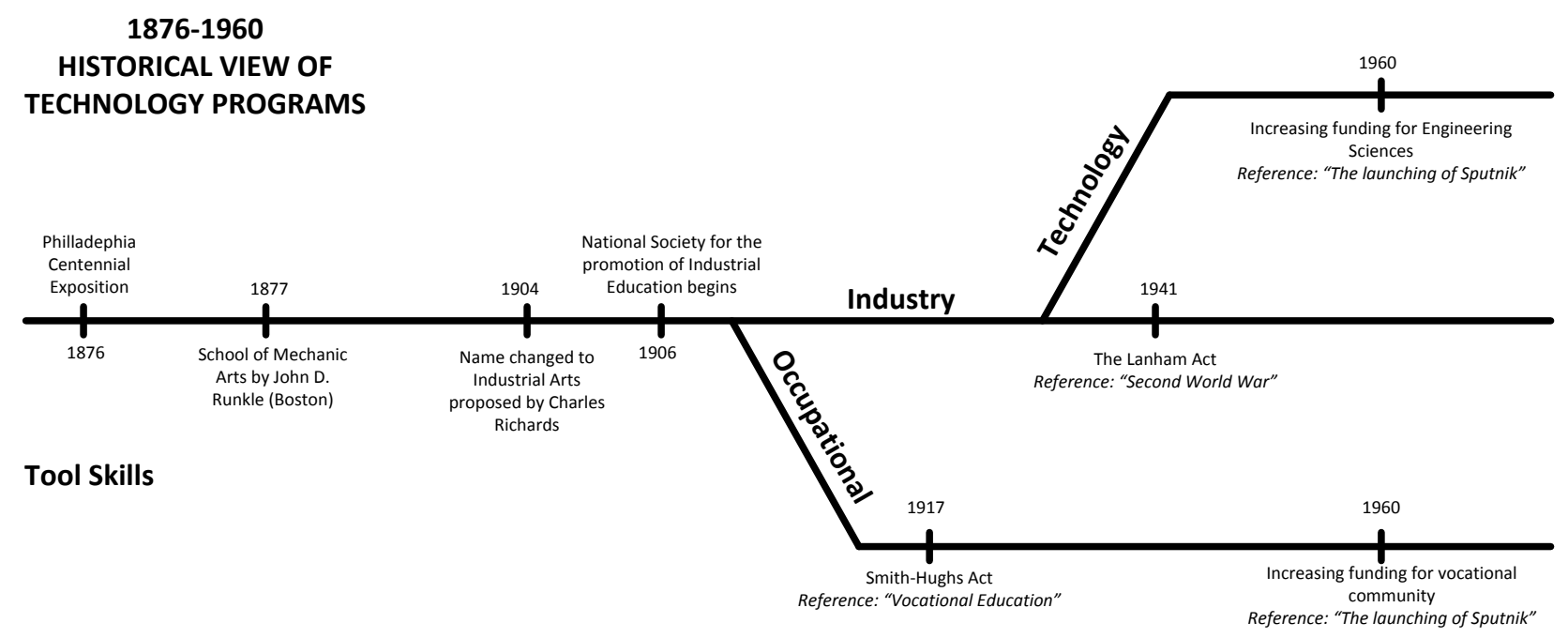

Figure 1

Educational philosophy, industrial demands, agriculture and national competition from a technological perspective influenced terms such as General Education, Postsecondary Education, and Vocational Education influenced by impacts from. The project method, intertwined with 
Russian influence and the cultural path for art and design, has affected post secondary education into what is commonly understood as college. European influence combined with industry and agriculture has also influenced what is now understood as general education. Federal funding, agriculture and U.S. industry and national security interest has also influenced what is now known as vocational education.

\section{Terms and misconceptions}

Engineers take basic science information and use the rules of mathematics to design new products and solve problems. An engineering degree is also an excellent background for other careers. Because engineering courses enhance creativity, problem solving skills, and understanding of technology, they provide a strong foundation for further studies in medicine, law, business, dentistry, and almost any other field ${ }^{[20]}$. Generally, technicians and engineers are not in competition unless it is on the ball field. They often work side-by-side on projects and their job functions commonly overlap. The difference is probably most pronounced right after graduating from school. Engineers tend to go to work applying the science and mathematics knowledge to solve problems and design processes and products ${ }^{[20]}$. Technicians tend to start their careers performing tests, collecting data, and assisting engineers. The demand for engineering support technicians is high and will continue to remain high ${ }^{[20]}$.

Engineering Education is the activity of teaching knowledge and principles related to the professional practice of engineering. Historically, engineering curricula have been based largely on an "engineering design" model over the last five decades in which engineering is taught only after a solid basis in science and mathematics (The "engineering science" model is sometimes unfairly characterized as the "Grinter Model", an attribution that ignores many other recommendations in the Grinter report, some of which are being independently revived today ${ }^{[5]}$. Technology Education is a study of technology, in which students learn about the processes and knowledge related to technology. Technology education is the study of "how people modify the natural world to suit their own purpose and generally refers to the diverse collection of processes and knowledge that people use to extend human capabilities and to satisfy human needs and wants" [11]. Technology literacy refers to one's ability to use, manage, evaluate, and understand technology ${ }^{[11]}$. Technology literacy is much more that just knowledge about computers and their application. It involves a vision where each person has a degree of knowledge about the nature, behavior, power, and consequences of technology from a real world perspective ${ }^{[4]}$.

\section{Conclusion}

Engineering Education is activity of instructing knowledge related to practice of engineering for occupational field. Technology Education is the study of technology through technology literacy, where students gain knowledge about the processes of modification of natural world. The role of the professional involved in these areas could be misunderstanding if the society does not recognize the difference between areas. Engineers tend to apply knowledge to solve problems and design process, and technicians tend to perform specific test assisting engineers. The misunderstanding and skewed assumptions of these terms utilized are due to lack of knowledge

about the foundations of engineering and technology education ${ }^{[11]}$. Historical perspectives 
describe an understanding of the nature of engineering education, technology education, and the roles of engineer and technician in society. History is addressing these issues in the occupation field harmonizing and bridging professional knowledge about these complex fields.

References

1. Alexander, M. J., \& Heilbronner, M. K. (1996). Dilution under Section 43(c) of the Lanham Act. Law and Contemporary Problems, 59, 2, 93-129.

2. Barlow, M. L. (1967). History of industrial education in the United States. Peoria: Charles A. Bennett.

3. Bennett, C.A. (1937). History of Manual and Industrial Education 1870-1917. Chas. A. Bennett Co., Inc. Publishers, Peoria, Illinois.

4. Dugger, W.E. (2008). The Perspective of Technology Education. International Technology Education Association.

5. Dym, C.L., Agogino, A.M., Eris, O., Frey, D.D., Leifer, L.J. (2005). Engineering Design Thinking, Teaching, and Learning. Journal of Engineering Education.

6. Foster, P. N. (1995). Industrial Arts/Technology Education as a Social Study: The Original Intent? Journal of Technology Education, 6, 2, 4-18.

7. Healey, D. (1958). The Sputnik and Western Defence. International Affairs (royal Institute of International Affairs 1944- ), 34, 2, 145-156.

8. Herschbach, D. (2009). Technology Education: Foundations and Perspectives. Homewood, American Technical Publishers, Inc.

9. Hilberry, C. B. (1958). Sputnik and the Universities. The Journal of Higher Education, 29, 7, 375-380.

10. Hillison, J. (1995). The Coalition that Supported the Smith-Hughes Act or a Case for Strange Bedfellows. Journal of Vocational and Technical Education, 11, 2, 4-11.

11. ITEA. (2000/2002/2007). Standards for Technological Literacy: Content for the Study of Technology. Reston, VA: Author.

12. Knoll, M. (1997). The project method: Its vocational education origin and international development. Journal of Industrial Teacher Education, 34(3), Retrieved from http://scholar.lib.vt.edu/ejournals/JITE/v34n3/Knoll.html?ref=abazatv.com

13. Lee, G. C. (1963). The Morrill Act and Education. British Journal of Educational Studies, 12, 1, 19-40.

14. Martin, G., \& Leutkemeyer, J. (1979). A historical and philosophical orientation to industrial arts. In G. Martin (Ed.), Industrial Arts Education: Retrospect; Prospect (pp. 25-27). Oxford: American Council on Industrial Arts Teacher Education.

15. National Defense Education Act of 1958. (1959). American Mathematical Monthly, 66, 1, 60.

16. Office of Elementary and Secondary Education. (2008). Retrieved from http://www2.ed.gov/about/offices/list/oese/impactaid/whatisia.html

17. Office of vocational and adult education. (2009, April 29). Retrieved from http://www2.ed.gov/about/offices/list/ovae/programs.html

18. Richards, C. (1922). Art in Industry. (pp. 10-11). New York: The Macmillan Company.

19. Smith, D. (1963). Industrial arts founded. (pp. 184-185). Muncie: Ball State University.

20. Technicians versus Engineer. NDT Education Resource Center, Brian Larson, Editor, 2001-2011. The Collaboration for NDT Education, Iowa State University. Retrieve from: http://www.ndt-ed.org/Careers/TechvsEng/techvseng.htm 